\title{
Quantitation of cis-Diamminedichloroplatinum II (Cisplatin)-DNA-Intrastrand Adducts in Testicular and Ovarian Cancer Patients Receiving Cisplatin Chemotherapy
}

Eddie Reed, Stuart H. Yuspa, Leonard A. Zwelling, Robert F. Ozols, and Miriam C. Poirier

Laboratory of Cellular Carcinogenesis and Tumor Promotion, Laboratory of Molecular Pharmacology, and Medicine Branch, Division of Cancer Treatment, National Cancer Institute, National Institutes of Health, Bethesda, Maryland 20205

\begin{abstract}
The antitumor activity of cis-diamminedichloroplatinum II (cisplatin) is believed to be related to its covalent interaction with DNA where a major DNA binding product is an intrastrand $\mathbf{N}^{\mathbf{7}}$ bidentate adduct on adjacent deoxyguanosines. A novel immunoassay was used to quantitate this adduct in buffy coat DNA from testicular and ovarian cancer patients undergoing cisplatin therapy. 44 out of 120 samples taken from 45 cisplatin patients had detectable cisplatin-DNA adducts. No adducts were detected in 18 samples of DNA taken from normal controls, patients on other chemotherapy, or patients before treatment. The quantity of measurable adducts increased as a function of cumulative dose of cisplatin. This was observed both during repeated daily infusion of the drug and over long-term, repeated 21-28 d cycles of administration. These results suggested that ádduct removal is slow even though the tissue has a relatively rapid turnover. Patients receiving cisplatin for the first time on 56-d cycles, and those given high doses of cisplatin as a "salvage" regimen, did not accumulate adducts as rapidly as patients on first time chemotherapy on 21- or 28-d cycles. Disease response data, evaluated for 33 cisplatin-treated patients, showed a positive correlation between the formation of DNA adducts and response to drug therapy. However, more data will be required to confirm this relationship. These data show that specific immunological probes can readily be applied to quantitate DNA adducts in patients undergoing cancer chemotherapy.
\end{abstract}

\section{Introduction}

cis-Diamminedichloroplatinum II (cisplatin), ${ }^{1}$ a potent anticancer agent, is the principal agent in the treatment of testicular (1) and ovarian cancers $(2,3)$, and is useful for several other malignancies (4-7). Novel methods of drug administration have allowed dosages to increase with acceptable toxicity (8-11), thus broadening the potential clinical spectrum. In vitro studies have

Address reprint requests to Dr. Poirier at LCCTP, DCE, Building 37, Room 3A23, National Cancer Institute, National Institutes of Health, Bethesda, MD 20205.

Received for publication 5 February 1985 and in revised form 25 October 1985.

1. Abbreviations used in this paper: cisplatin, cis-diamminedichloroplatinum II; CHIP(S), cytoxan, hexamethylmelamine, irradiation, cisplatin, with or without radiosensitizer, CTX/DDP, cytoxan, cisplatin; ELISA, enzyme-linked immunosorbent assay; HD-DDP, high-dose cisplatin; PVB, cisplatin, velban, bleomycin; PVeBV, cisplatin, epidophyllotoxin, bleomycin, velban; WBC, white blood cell count.

The Journal of Clinical Investigation, Inc.

Volume 77, February 1986, 545-550 shown that cellular lethality is proportional to cisplatin-DNA modification, which includes formation of interstrand cross-links and intrastrand adducts $(12,13)$. A bidentate, $N^{7}$-deoxy $(\mathrm{GpG})$ intrastrand platinum adduct is found in DNA from cultured cells and from animal tissues following cisplatin exposure (1416). In cisplatin-exposed cultured L1210 cells, this adduct comprises up to $60 \%$ of the total cisplatin-DNA modification determined by high-pressure liquid chromatography (15). We have prepared and characterized a rabbit antiserum with primary specificity for the $\mathrm{N}^{7}$-deoxy $(\mathrm{GpG})$ intrastrand adduct (16). Using enzyme-linked immunosorbent assay (ELISA), with modifications outlined below, it has been possible to quantitate this adduct in DNA isolated from several different sources at a sensitivity of one adduct in $10^{8}$ nucleotides or 25 attomol $/ \mu \mathrm{g}$ DNA (14, $16,17)$. This level of detectability has provided the unique opportunity to attempt to measure DNA modification in tissues from patients receiving cisplatin chemotherapy, and to look for a correlation between adduct formation and disease response. While tumor samples would be the most appropriate to measure, such tissues are not readily obtainable and would not allow for repetitive samplings. Therefore we chose to monitor cisplatinDNA adduct formation in nucleated cells obtained from the buffy coat of the readily accessible peripheral blood of chemotherapy patients.

\section{Methods}

Cisplatin administration to patient groups. Individuals studied were being treated for either ovarian or testicular cancer by the Medicine Branch of the National Cancer Institute. These patients were given cisplatin therapy as part of approved experimental protocols and comprised the following groups: (a) cisplatin, velban, bleomycin (PVB)/cisplatin, epidophyllotoxin, bleomycin, velban (PVeBV), testicular cancer patients receiving their first course of chemotherapy on 21-d (PVB) or 28-d (PVeBV) cycles; (b) cytoxan, cisplatin (CTX/DDP), ovarian cancer patients receiving their first course of chemotherapy on 28-d cycles; $(c)$ cytoxin, hexamethylmelamine, irradiation, cisplatin, with or without radiosensitizer [CHIP(S)], ovarian cancer patients receiving their first course of chemotherapy on 56-d cycles; and ( $d$ ) high-dose cisplatin (HD-DDP), ovarian cancer patients receiving cisplatin as single-agent therapy on 28d cycles, having failed one or more courses of previous platinum or nonplatinum chemotherapy. Cisplatin dose varied with protocol and was $20 \mathrm{mg} / \mathrm{M}^{2}$ per day $\times 5(\mathrm{PVB}), 30 \mathrm{mg} / \mathrm{M}^{2}$ per day $\times 5$ (CHIPS), or $40 \mathrm{mg} / \mathrm{M}^{2}$ per day $\times 5$ (PVeBV, CTX/DDP, and HD/DDP). Control groups were untreated normal volunteers and patients on nonplatinum combination chemotherapy for non-Hodgkins lymphoma. Some of the patients were studied for adducts before receiving any cisplatin or other chemotherapy and therefore served as their own controls.

Cisplatin chemotherapy was given in courses comprised of three to five cycles. In each cycle the drug was administered as a 30 -min daily intravenous infusion on each of five consecutive days and no cisplatin was given for the remainder of the cycle. The drug was administered in standard fashion (1) for dose regimens of $20 \mathrm{mg} / \mathrm{M}^{2}$ per day $\times 5$ and 30 
$\mathrm{mg} / \mathrm{M}^{2}$ per day $\times 5$, and in "high dose" fashion (9) for dose regimens of $40 \mathrm{mg} / \mathrm{M}^{2}$ per day $\times 5$. In standard cisplatin administration, the drug is reconstituted in normal saline just before intravenous infusion and hydration is with 3 liters/d of normal saline. In high dose administration, the drug is reconstituted in 3\% saline and hydration is with 6 liters/d of normal saline. More detailed accounts of these regimens may be found elsewhere $(1,9)$.

On the morning following an infusion, 35-50 ml of blood was obtained via venipuncture, centrifuged $\left(20 \mathrm{~min}, 5,000 \mathrm{~g}, 4^{\circ} \mathrm{C}\right)$, and the nucleated cells (the buffy coat) were aspirated and frozen at $-20^{\circ} \mathrm{C}$ until DNA isolation. During the days of therapy, patients' white blood cell counts ranged between 3,000 and $10,000 / \mathrm{ml}^{3}$.

DNA preparation and ELISA. DNA was extracted from buffy coat cells by $\mathrm{CsCl}$ gradient centrifugation (18) within $1 \mathrm{mo}$ of the time the blood was drawn. Gradients were at neutral $\mathrm{pH}$ (7.4), maintained by $0.01 \mathrm{M}$ Tris buffer. This DNA ( $99.4 \%$ pure) was dialyzed against water and quantitated by absorbance at $260 \mathrm{~nm}$. The DNA samples were assayed for cisplatin-DNA adducts by ELISA as reported by Poirier et al. (16) with modifications. Polyvinylchloride U-bottom microtiter plate wells (Dynatech, Inc., Alexandria, VA) were coated sequentially with DEAE-dextran and $0.5 \mathrm{ng}$ of calf thymus DNA, either unmodified or modified to $4.3 \%$ with cisplatin. In separate tubes, antibody to cisplatinmodified DNA (diluted 1:60,000) was reacted with standard or sample DNAs for $30 \mathrm{~min}$ at $37^{\circ} \mathrm{C}$. Subsequently, the mixture was added to the microtiter plates so that remaining free antibody could bind cisplatinDNA coated on the plate. After 90 min of further incubation, soluble antigen-antibody complexes were removed by three washes with phosphate-buffered saline-Tween. Excess alkaline phosphatase conjugate (goat-anti-rabbit-IgG, Sigma Chemical Co., St. Louis, MO) was then added to the wells and incubated $90 \mathrm{~min}$ to interact with the residual bound rabbit anti-cisplatin-DNA antibody. After washing again, $1 \mathrm{M}$ diethanolamine buffer at $\mathrm{pH} 8.6$, containing excess $p$-nitrophenyl-phosphate, was added to each well. The extent of hydrolysis of $p$-nitrophenolphosphate to $p$-nitrophenol was proportional to the quantity of bound rabbit anti-cisplatin-DNA. A Titertek Multiskan colorimetric microtiter plate reader was used at $405 \mathrm{~nm}$ to determine $p$-nitrophenol. The quantity of cisplatin DNA in unknown samples was inversely related to the degree of substrate conversion; and dependent upon comparison with a standard curve. The ELISA standard curve 50\% inhibition, under the assay conditions described, was at $10 \pm 4$ fmol of cisplatin-DNA (mean \pm range). DNA samples were assayed as native, with 30-35 $\mu \mathrm{g}$ of sample DNA per well and $35 \mu \mathrm{g}$ of unmodified calf thymus DNA in the standard curve wells. Each unknown DNA sample was assayed 2-3 times by ELISA. Samples were not considered positive unless they produced $>20 \%$ inhibition in the assay.

Determination of the effect of a heterogenous cell population on DNA recovery and cisplatin-DNA adduct recovery. L1210 cells were grown in suspension culture in RPMI 1630 medium supplemented with 15\% fetal calf serum. Cellular DNA was radiolabeled in the exponential growth phase with $\left[2-{ }^{14} \mathrm{C}\right]$ thymidine $(58 \mu \mathrm{Ci} / \mathrm{mmol}$, New England Nuclear, Boston, $\mathrm{MA}$ ) for $20 \mathrm{~h}$ at $37^{\circ} \mathrm{C}$ at $0.01 \mu \mathrm{Ci} / \mathrm{ml}$. Radioactive label was removed by centrifugation of cells and resuspension in fresh medium. After incubation in fresh medium for $2 \mathrm{~h}$, cisplatin was dissolved in $50 \mathrm{ml}$ of normal saline and added to 1 liter of cell suspension to form a cisplatin concentration of $200 \mu \mathrm{M}$ and a cell concentration of $1.2 \times 10^{6} / \mathrm{ml}$. Cisplatin exposure for $2 \mathrm{~h}$ at $37^{\circ} \mathrm{C}$ was followed by centrifugation of cells and resuspension in fresh medium. 10 aliquots of $1 \times 10^{8}$ cells were made, and then total radioactive counts per minute and total cell number were determined for each aliquot. Cell number was measured using a Coulter counter, model ABI (Coulter Electronics, Inc., Hialeah, FL). Counts per minute were quantitated by liquid scintillation spectrometry.

Separately, $35 \mathrm{~cm}^{3}$ of peripheral blood was obtained via venipuncture from each of six normal volunteers and buffy coats were prepared. One buffy coat preparation was added to each of six L1210 cell aliquots, mixed by inverting six times, and frozen overnight before DNA isolation. Four L1210 aliquots were used as controls. DNA was prepared by buoyant density $\mathrm{CsCl}_{2}$ gradient centrifugation of all 10 samples concurrently, and
DNA recovery was determined by measurements of radioactivity and $A_{260}$. Cisplatin-DNA adducts were determined by ELISA, and adduct recovery was calculated as the ratio of attomoles of adduct per cpm.

Data analysis. Adduct analyses were performed on 138 samples collected from a total of 53 individuals. Patients in the treatment groups outlined above were studied one or more times during their course of cisplatin chemotherapy. Individuals in the control groups were generally studied only once. Linear regression analyses of data points in each patient group were performed by computer. Statistical significance was calculated by the Fisher Exact Test as described by Armitage (31). Results of the two-sided test are given. $P$ values of $\leq 0.05$ are considered statistically significant. Disease response criteria were defined as complete response (eradication of all known disease), partial response ( $>50 \%$ reduction in mass of all known disease), or no response.

\section{Results}

Assay conditions and sensitivity. A summary of the results from ELISA of 138 DNA samples, grouped by treatment, is shown in Table I. Most patients were studied during every cycle of chemotherapy. Occasionally, patients were entered on the study while they were neutropenic such that insufficient DNA was obtained to perform the assay. The limit of sensitivity of the assay, using the assay modifications noted above, was $\sim 25$ attomol $\left(10^{-18} \mathrm{M}\right)$ of adduct per microgram of DNA. As shown in Table I, all samples were negative when DNA was assayed from normal volunteers, patients on nonplatinum chemotherapy, and patients before any platinum chemotherapy was administered. Thus the assay provided extreme sensitivity and high specificity, both requirements for the desired clinical studies and consistent with the experimental studies reported previously $(16,17)$.

DNA adduct formation. Since there existed no published data on the formation of cisplatin-DNA adducts in human cancer patients prior to this study, initial blood samples were drawn at

Table I. Summary of ELISA Results from 138 Peripheral Blood DNA Samples

\begin{tabular}{|c|c|c|c|c|}
\hline \multirow[b]{2}{*}{ Patient group } & \multirow[b]{2}{*}{$\begin{array}{l}\text { Number of } \\
\text { individuals }\end{array}$} & \multirow[b]{2}{*}{$\begin{array}{l}\text { Number of } \\
\text { individuals } \\
\text { positive } \geq \text { once }\end{array}$} & \multicolumn{2}{|c|}{ Blood samples } \\
\hline & & & $\begin{array}{l}\text { Posi- } \\
\text { tive }\end{array}$ & $\begin{array}{l}\text { Nega- } \\
\text { tive }\end{array}$ \\
\hline PVB/PVeBV & 11 & 8 & 11 & 23 \\
\hline CTX/DDP $\ddagger$ & 13 & 9 & 11 & 16 \\
\hline CHIP(S)§ & 8 & 6 & 8 & 12 \\
\hline HD-DDP" & 13 & 9 & 14 & 25 \\
\hline Normal volunteers & 4 & & 0 & 4 \\
\hline $\begin{array}{l}\text { Patients on non-cis } \\
\text { therapy }\end{array}$ & 4 & & 0 & 4 \\
\hline \multicolumn{5}{|c|}{$\begin{array}{l}\text { Samples taken from } \\
\text { cisplatin-treated } \\
\text { patients before any } \\
\text { chemotherapy was }\end{array}$} \\
\hline given & 10 & & 0 & 10 \\
\hline
\end{tabular}

* Lower limit of sensitivity is 25 attomol of adduct/g DNA. Testicular cancer patients on 21 - or 28-d cycles.

‡ Ovarian cancer patients on 28 -d cycles.

$\S$ Ovarian cancer patients on 56-d cycles.

"Ovarian cancer patients on salvage chemotherapy and in 28-d cycles. Control groups. 


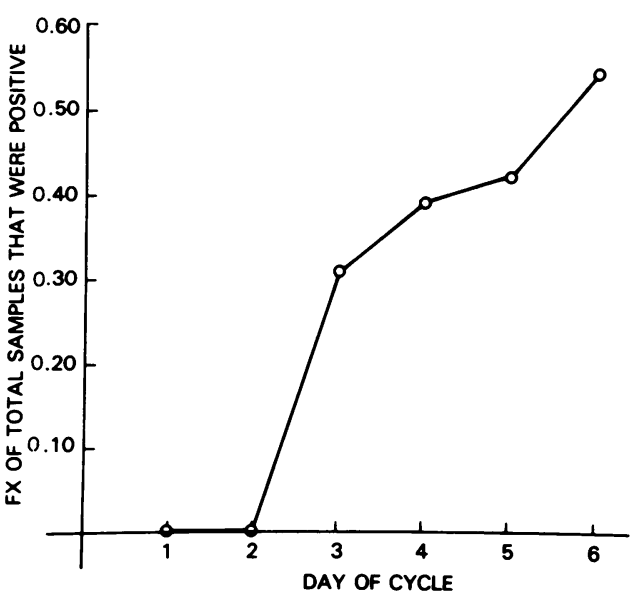

Figure 1. Fraction of samples positive in the cisplatin-DNA ELISA among all samples at different times from patients on their first cycle of chemotherapy. Cisplatin was given as a $1-\mathrm{h}$ infusion daily on days 1 through 5 of the cycle. Samples were collected in the morning of the day following (12-18 h after) the infusion. Day 1 samples were collected before any cisplatin was administered. DNA samples were prepared and ELISAs performed as described in Methods.

random during the treatment cycle. Fig. 1 shows adduct accumulation in DNA samples from previously untreated patients studied on the first cycle of their first course of cisplatin chemotherapy. There is a greater proportion of positive samples toward the end of a cycle, suggesting that adduct levels increase with successive doses of cisplatin. Since $35-50 \mathrm{ml}$ of blood was drawn for each adduct determination, it was not feasible to study a single patient on each of the five days following cisplatin infusions. However, these data demonstrated that maximum adduct levels could be expected the day after the last infusion, and subsequent samples were obtained at this time. Even at this point, only $60 \%$ of the patients were positive by this assay. Measurable cisplatin-DNA adducts in positive samples from patients in each of the four treatment groups is plotted in Fig. 2 as adduct level vs. cumulative cisplatin dose. Pretreatment values for each group are at the origin. Clearly, adducts increase with dose in patients receiving their first course of cisplatin therapy on $21-$ or $28-\mathrm{d}$ cycles (Fig. 2, $A$ and $B$ ), while the correlation is less clear in patients on 56-d cycles or those who have failed previous chemotherapy (Fig. 2, $C$ and $D$ ). Linear regression analyses of the data for testicular (Fig. $2 \mathrm{~A}$ ) and ovarian (Fig. $2 \mathrm{~B}$ ) cancer patients receiving their first course of chemotherapy on 21- or 28-d cycles shows that blood cell DNA adducts appeared to increase in a dose-dependent fashion. The slopes and correlation coefficients for the adduct accumulation data in the two groups are virtually identical. For patients receiving their first course of chemotherapy on 56-d cycles (Fig. $2 C$ ), the data points show considerable scatter, resulting in a correlation coefficient of only 0.48 . This increase in measurable adduct levels appears to be less consistent when patients have a longer cycle time interval, suggesting that substantial adduct removal does occur within the 56-d time period. For samples from patients receiving cisplatin as a single agent, having failed one or more courses of chemotherapy previously (Fig. $2 \mathrm{D}$ ), adducts increased slowly with cisplatin dose. This is illustrated by the slope which is less than half of, and the correlation coefficient which is substantially lower than, values for the groups in Fig. $2 A$ and $B$.

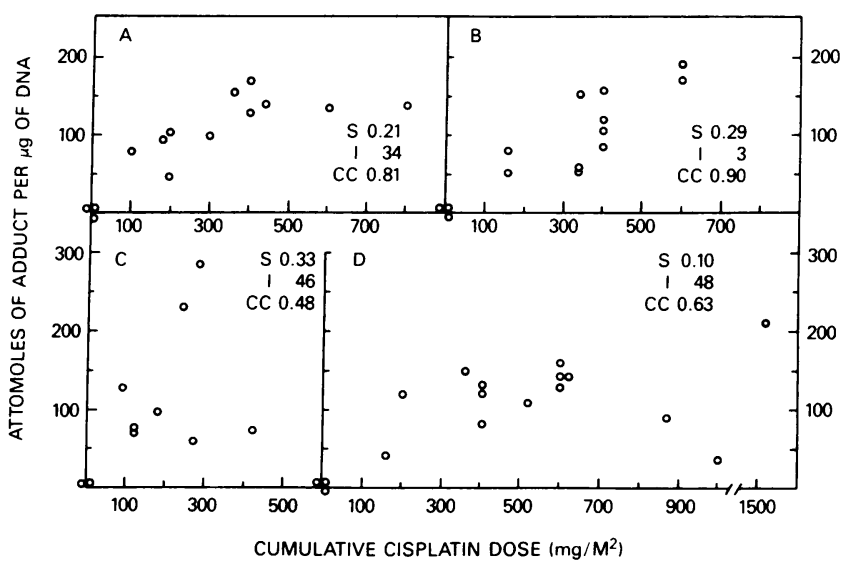

Figure 2. Cisplatin-DNA adduct levels measured by ELISA for samples from individuals in each of four treatment groups as a function of cumulative cisplatin dose. $A$ shows data from the PVB/PVeBV group; $B$, the CTX/DDP group; $C$, the CHIP(S) group; and $D$, the HD-DDP group (see Methods). Each group of results was subjected to linear regression analysis and the parameters generated are shown on the figure, although the lines were not drawn. $S$, slope; $I$, intercept; $C C$, correlation coefficient.

Combined values for positive samples from all patients receiving chemotherapy for the first time on $21-$ or $28-\mathrm{d}$ cycles (Fig. 2, $A$ and $B$ ) are presented in Fig. 3 as a function of $(A)$ cumulative cisplatin dose or $(B)$ the cycle of treatment. Linear regression analysis of the data in Fig. $3 B$ shows good linear fit, illustrating that adducts accumulate as a function of cycle. These data imply that cisplatin-DNA adduct removal is slow, and that some adducts persist for at least $28 \mathrm{~d}$.

Correlation between response to cisplatin treatment and adduct formation. Disease response data are available on 33 of the cisplatin patients from whom blood was drawn for ELISA. Of these, 12 were given cisplatin as a single agent, and 21 were exposed to combination chemotherapy that included cisplatin. Table II shows disease response data for these patients, grouped by single agent vs. combination chemotherapy, and separated by groups into those who never showed measurable adduct levels and those who had at least one positive adduct determination

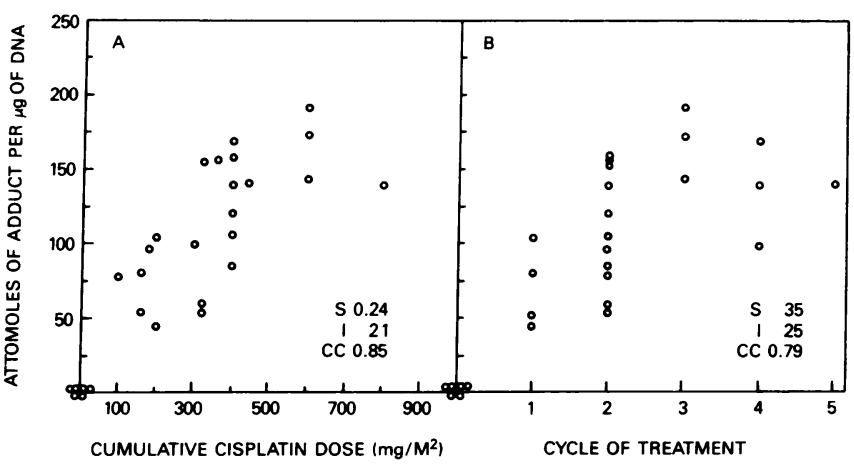

Figure 3. Cisplatin-DNA adduct determination on samples from all patients on their first course of 21- and 28-d cycle chemotherapy. Adduct levels are expressed as a function of cisplatin cumulative dose $(A)$, and cycle of treatment in the first course $(B)$. Both plots are of the same data. $S$, slope; $I$, intercept; and $C C$, correlation coefficient; all are from linear regression analysis (lines not drawn). 
Table II. Disease Response in All Patients Grouped by Treatment and by Adduct Status

\begin{tabular}{|c|c|c|c|c|c|c|}
\hline Treatment & $\begin{array}{l}\text { Number of } \\
\text { patients }\end{array}$ & $\begin{array}{l}\text { Number } \\
\text { CR }\end{array}$ & $\begin{array}{l}\text { Number } \\
\text { PR }\end{array}$ & $\begin{array}{l}\text { Number } \\
\text { no response }\end{array}$ & $\begin{array}{l}\text { Percent responding } \\
(\mathrm{CR}+\mathrm{PR})\end{array}$ & $\begin{array}{l}\text { Cumulative cisplatin dose } \\
\text { (mean } \pm \text { SD) }\end{array}$ \\
\hline & & & & & & $m g / M^{2}$ \\
\hline \multicolumn{7}{|l|}{ A } \\
\hline Single agent & 12 & & & & & \\
\hline Never positive & 4 & 0 & 0 & 4 & $0 \quad(0 / 4)$ & $756 \pm 445$ \\
\hline Positive $\geq$ once & 8 & 1 & 3 & 4 & $50 \%(4 / 8)$ & $876 \pm 395$ \\
\hline \multicolumn{7}{|l|}{ B } \\
\hline Combination therapy & 21 & & & & & \\
\hline Never positive & 6 & 1 & 2 & 3 & $50 \%(3 / 6)$ & $543 \pm 184$ \\
\hline Positive $\geq$ once & 15 & 6 & 7 & 2 & $87 \%(13 / 15)$ & $575 \pm 219$ \\
\hline \multicolumn{7}{|l|}{$A+B$} \\
\hline Never positive & 10 & 1 & 2 & 7 & $30 \%(3 / 10)$ & \\
\hline Positive $\geq$ once & 23 & 7 & 10 & 6 & $74 \%(17 / 23)$ & \\
\hline
\end{tabular}

CR, complete response (see text); PR, partial response (see text).

during cisplatin chemotherapy. Of a total of 12 patients on singleagent therapy, eight formed adducts on at least one cycle of their treatment course and four of these responded to therapy, while four patients did not have measurable adduct levels and did not respond to therapy. For 21 patients on combination therapy, 3 of 6 who never formed measurable adducts responded to treatment, whereas 13 of 15 who formed adducts on one or more cycles responded to treatment. Combination of the data for single agent and multiple agent therapy shows that 17 of 23 who formed adducts on one or more cycles of treatment responded to therapy, whereas only 3 of 10 of the patients who never showed measurable adduct levels responded to treatment $(P=0.048)$. These three patients were treated with combination chemotherapy, leaving open the possibility that the other drugs in the regimen may have been responsible for the response seen. The table also shows that both the responding and nonresponding groups received essentially the same amount of cisplatin in their therapeutic regimens.

Lack of correlation between adduct level and the relative number of long-lived peripheral blood cells. Because peripheral blood has several different types of nucleated cells, we sought to determine if a relative change in the number of short-lived or long-lived cells might explain variation in adduct levels in the samples studied. To address this question, we reviewed the medical records of 9 patients whose blood DNA was never positive in the assay and 10 patients from matched treatment protocols having the highest adduct levels in their respective groups. Information on the white blood cell counts (WBC) and differential on the days that samples were taken were obtained on nine patients who never had measurable adducts, and 10 protocolmatched, adduct-forming individuals. These data are summarized in Table III. Granulocytes, bands, and metamyelocytes were grouped together and characterized as short-lived cells; lymphocytes, monocytes, eosinophils, and basophils were grouped together and characterized as long-lived cells. Since the relative percentage of long- and short-lived cells are the same in both groups, the tendency to develop measurable levels of cisplatin-DNA adducts in peripheral blood cell DNA is independent of the relative proportion of long-lived cells that may be present.

Effect of the heterogenous WBC population on cisplatin-DNA adduct recovery. In an attempt to determine whether or not the presence of buffy coat cells caused a loss in recovery of cisplatinDNA adduct, $\left[{ }^{14} \mathrm{C}\right] \mathrm{TdR}$ prelabeled $\mathrm{L} 1210$ cells were treated with cisplatin and mixed with buffy coat cells from normal volunteers. Cisplatin-DNA adduct recovery was determined by calculating the ratio of ${ }^{14} \mathrm{C}$ counts (indicating quantity of L1210 cell DNA) to attomoles of adduct measured in a given portion of DNA. In aliquots of L1210 cells mixed with human buffy coats, the attomole adduct/cpm ratio was $29.9 \pm 7$ (mean \pm SD). In aliquots of the $\mathrm{L} 1210$ controls the ratio was $34.6 \pm 7$. Thus the presence of the buffy coat cells did not affect the yield of cisplatin-DNA adducts. In addition, the yield of DNA was not altered by the

Table III. White Blood Cell Counts and Differentials in Matched Patient Groups:

Those Who Did Not Form Adducts in Peripheral Blood Compared with Those Who Formed the Highest Adduct Levels*

\begin{tabular}{|c|c|c|c|c|c|c|}
\hline \multirow[b]{2}{*}{ Patient group } & \multirow[b]{2}{*}{ No. patients } & \multirow[b]{2}{*}{ No. determinations } & \multirow[b]{2}{*}{ WBC count } & \multicolumn{2}{|c|}{ White cell differential } & \multirow[b]{2}{*}{ Mean cumulative cisplatin dose } \\
\hline & & & & Short-lived & Long-livedf & \\
\hline & & & & & & $m g / M^{2}$ \\
\hline Never pos & 9 & 23 & $5.7 \pm 3.5$ & $78 \pm 9$ & $22 \pm 9$ & 587 \\
\hline Pos $\geq$ once & 10 & 10 & $5.2 \pm 1.8$ & $76 \pm 12$ & $24 \pm 12$ & 583 \\
\hline
\end{tabular}

Units are thousands of cells per cubic millimeter. ${ }^{*} \mathrm{WBC}$ and differential counts expressed as mean \pm 2 SD from the mean. $\ddagger$ The percentages of the total number of WBCs that were short-lived and long-lived cells, respectively (see text). 
presence of the buffy coat cells. $35 \mathrm{~cm}^{3}$ of normal donor buffy coat cells alone will yield 300-350 $\mu$ g of DNA (data not shown). In this experiment, the L1210 cells alone yielded $698.5 \pm 57$ (mean $\pm \mathrm{SD}) \mu \mathrm{g}$ of DNA, while the yield from combined cells was $1038.0 \pm 121 \mu \mathrm{g}$ of DNA. Thus, by difference, the usual quantity of buffy coat cell DNA was obtained, and the yield of L1210 DNA was the same in both groups.

\section{Discussion}

Using a highly sensitive immunoassay specific for an intrastrand, $\mathrm{N}^{7}$-deoxy(GpG)-diamminelplatinum adduct, it has been possible to monitor levels of this adduct in buffy coat DNA of cancer patients under conditions where adduct recovery is complete. These studies clearly demonstrate that adduct levels increase with cumulative cisplatin dose. In patients who have received no previous chemotherapy, adducts also increase with each drug treatment when cycles are within $28 \mathrm{~d}$. However, when cycle time is extended to $56 \mathrm{~d}$, an increase in measurable adducts is not obvious. In addition, there appears to be a positive correlation between the formation of measurable adduct levels and disease response to cisplatin treatment, although this relationship requires further investigation. Since adducts increase as a function of 21 - and 28-d cycles of treatment (Fig. 3), the data suggest that at least some adducts persist for longer than $28 \mathrm{~d}$. Pharmacokinetic studies measuring free cisplatin and protein-bound cisplatin in cancer patients $(19,20)$ have been invaluable in the study of drug clearance, but these measurements have demonstrated limited utility for understanding the molecular basis by which cisplatin effects tumor-cell death in the intact host. In vitro studies have clearly shown that cisplatin-induced cell death is directly related to cisplatin-DNA modification $(12,13,21$, 23 ), and the ability to monitor adducts may make a similar correlation possible in vivo.

Several different types of cisplatin-DNA modification have been observed $(12,13,15,21)$, but in most cases their proportion of the total cisplatin-DNA binding and their relative contributions to the total biologic effect are unknown. Zwelling et al. (21) have shown that cell death in L1210 cells correlates directly with interstrand cisplatin-DNA crosslinks, but the method used, alkaline elution, measures only $\sim 1 \%$ of the total quantity of cisplatin bound to DNA $(12,13)$. The instrastrand adduct measured in this study has been shown to comprise $\sim 60 \%$ of the total cisplatin-DNA binding products in cisplatin exposured L1210 cells (15), and is probably not the only cisplatin-DNA adduct formed in human DNA. Other adducts formed in vivo have not been extensively studied. Additional studies will be required to establish the relative importance of this adduct. It is reasonable to assume that multiple cisplatin-DNA adducts $(23,29)$ may interplay in causing mutagenesis and cell death.

The results reported here, quantitating adduct formation in human DNA, are influenced by two factors of importance in the interpretation of the data: the high turnover rate of the tissue studied, and the dose schedule of cisplatin. The increase in adduct levels seen with the cumulative dose of cisplatin possibly reflects not only adduct accumulation in lymphocytes, but also DNA damage incurred in the bone marrow in granulocyte precursor cells. Reutilization of adduct is probably less likely here since a preformed bidentate adduct is an unlikely precursor for nucleic acid synthesis. Granulocytes have a blood half-life of $<1 \mathrm{~d}$ (24) and consistently accounted for $55-80 \%$ of the nucleated cells in specimens we collected. Human $\mathrm{T}$ lymphocytes have a mean life span of $4.4 \mathrm{yr}(25)$ and there is no current data on the life span of B lymphocytes (32). Total lymphocytes in our samples comprised $15-40 \%$ of the nucleated cells. The fact that an increase in adduct concentration occurs in a tissue with such high turnover is remarkable, particularly when there appears to be no correlation between a patient's relative number of lymphocytes and his tendency to form adducts. Adducts appear to increase in those patients treated on 21- or 28-d cycles, but not in patients treated on 56-d cycles (Fig. $2 C$ ). This suggests that substantial removal of this adduct from circulating cells occurs within the 56-d cycle interval. As regards the dose regimen, the data presented here lends itself to several projections. Many cancer centers currently treat certain malignancies with a cisplatin regimen of a single infusion per cycle with a dose $>100 \mathrm{mg} / \mathrm{M}^{2}$, including lung cancer (4), head and neck malignancies (5), and others (6). How adduct persistence may be affected by single cisplatin doses of this magnitude is unclear. In one study on ovarian cancer, similar disease response rates were seen between two cisplatin regimens, one containing a single cisplatin infusion per cycle and the other having daily infusions for $5 \mathrm{~d}$ (30). The former regimen resulted in half the total cisplatin dose of the latter. If further study should bear out the value of adduct measurements, one could ascertain the adduct profiles generated by different treatment regimens and perhaps treat with the less toxic regimen while assuring comparable antitumor activity.

Of the many possible sequelae cisplatin may produce, one of the most ominous is the generation of second malignancies, reports of which have begun to appear in the literature $(26,27)$. It is possible that the slow rate of intrastrand adduct removal may contribute to the chemotherapeutic potency of cisplatin. However, this adduct persistency may also be related to the eventual development of treatment-related neoplasia since similar phenomena are known to occur in animal models. For example, in neonatal rats exposed to ethylnitrosourea, a neurooncogenic effect in brain tissue has been shown to correlate directly with the slow rate of repair of the ethylnitrosourea-DNA adduct (28). If reports of cisplatin-related neoplasia become more frequent, this adduct persistency may well pose a difficult therapeutic dilemma. Data generated in studies such as ours may be useful in determining dose-response relationships and adduct accumulation levels associated with risks for second malignancies.

Studies using the ELISA to quantitate adducts in animal models may become useful adjuncts for designing drug treatment protocols and for elucidating mechanisms underlying drug efficacy in vivo. Concomitant studies using human cancer cell lines should be useful for studying mechanisms of drug resistance on a molecular level, and for investigating how that resistance may be overcome. Together these approaches may lead to more effective modes of treatment in the clinic.

\section{Acknowledgments}

Dr. Stephen J. Lippard of the Massachusetts Institute of Technology supplied immunogen cisplatin-DNA and information concerning cisplatin-DNA chemistry. We wish to acknowledge the expert technical assistance of Elroy Patterson, Curtis Thill, Sam Eng, Huong Cao, and Nga Nguyen. Margaret Wesley provided guidance in the statistical evaluation of patient response data. 


\section{References}

1. Einhorn, L. H., and J. Donohue. 1977. cis-Diamminedichloroplatinum, vinblastine, and bleomycin combination chemotherapy in disseminated testicular cancer. Ann. Intern. Med. 87:293-298.

2. Young, R. C. 1979. Gynecologic malignancies. In Cancer Chemotherapy. H. Pinedo, editor. Excerpta Medica, Amsterdam. 340-375.

3. Young, R. C. D. D. Von Hoff, P. Gormley, R. Makuch, J. Cassidy, D. Howser, and J. M. Bull. 1979. cis-Dichlorodiammineplatinum (II) for the treatment of advanced ovarian cancer. Cancer Treat. Rev. 63: 1539-1544.

4. Gralla, R. J., E. S. Casper, D. P. Kelsen, D. W. Braun, M. E. Dukeman, N. Martini, C. W. Young, and R. B. Golby. 1981. Cisplatin and vindesine combination chemotherapy for advanced carcinoma of the lung: a randomized trial investigating two dosages schedules. Ann. Intern. Med. 95:414-420.

5. Randolph, V. L., A. Vallejo, R. H. Spiro, J. Shah, E. Strong, A. Huvas, and R. Wittes. 1978. Combination therapy of advanced head and neck cancer: induction of remissions with diamminedichloroplatinum (II), bleomycin, and radiation therapy. Cancer (Phila.). 41:460467.

6. Loehrer, P. J., and L. H. Einhorn. 1984. Cisplatin. Ann. Intern. Med. 100:704-713.

7. Seski, J. C., C. L. Edwards, J. Herson, and F. N. Rutledge. 1982. Cisplatin chemotherapy for disseminated endometrial cancer. Obstet. Gynecol. 59:225-228.

8. Howell, S. B., C. L. Pfeifle, W. E. Wung, R. A. Olshen, W. E. Lucas, J. L. Yon, and M. Green. 1982. Intraperitoneal cisplatin with systemic thiosulfate protection. Ann. Intern. Med. 97:845-851.

9. Ozols, R. F., B. J. Corden, J. Jacob, M. N. Wesley, Y. Ostchega, and R. C. Young. 1984. Highdose cisplatin in hypertoxic saline. Ann. Intern. Med. 100:19-24.

10. Mavligit, G. M., R. Benjamin, Y. Z. Patt, N. Jaffe, V. Chuang, S. Wallace, J. Murray, A. Ayala, S. Johnston, E. M. Hersh, and D. B. Calvo. 1981. Intraarterial cis-platinum for patients with inoperable skeletal tumors. Cancer (Phila.). 1:1-4.

11. Pritchard, J., G. Mauligit, R. Benjamin, Y. Pratt, D. Calvo, S. Hall, G. Body, and S. Wallace. 1979. Regression of regionally confined melanoma with intraarterial cis-dichlorodiammineplatinum (II). Cancer Chemother. Rep. 63:555-558.

12. Roberts, J. J., and M. F. Pera, Jr. 1983. DNA as a target for anticancer coordination compounds. In Platinum, Gold, and Other Metal Chemotherapeutic Agents. S. J. Lippard, editor. American Chemical Society, Washington, DC. 3-25.

13. Plooy, A. C. M., M. van Diik, and P. H. M. Lohman. 1984. Induction and repair of DNA cross-links in Chinese hamster ovary cells treated with various platinum coordination compounds in relation to platinum binding to DNA, cytotoxicity, mutagenicity, and antitumor activity. Cancer Res. 44:2043-2051.

14. Reed, E., L. A. Zwelling, C. L. Litterst, R. F. Ozols, S. H. Yuspa, and M. C. Poirier. 1984. DNA adduct formation subsequent to cis-platinum drug treatment in cancer patients and tumor-bearing rodents. Proc. Am. Assoc. Cancer Res. 25:368. (Abstr.)

15. Eastman, A. 1984. Characterization of the interaction of cisdichloro(ethylenediammine)platinum (II) with the DNA of sensitive and resistant L1210 cells. Proc. Am. Assoc. Cancer Res. 25:367. (Abstr.)

16. Poirier, M. C., S. J. Lippard, L. A. Zwelling, H. M. Ushay, D.
Kerrigan, C. C. Thill, R. M. Santella, D. Grunberger, and S. H. Yuspa. 1982. Antibodies elicited against cis-diamminedichloroplatinum (II)DNA adducts formed in vivo and in vitro. Proc. Natl. Acad. Sci. USA. 79:6443-6447.

17. Lippard, S. J., H. M. Ushay, C. M. Merkel, and M. C. Poirier. 1983. Use of antibodies to probe the stereochemistry of antitumor platinum drug binding to DNA. Biochemistry. 22:5165-5168.

18. Flamm, W. G., M. L. Birnstiel, and P. M. B. Walker. 1969. In Subcellular Components. Preparation and Fractionation. G. Birnie and S. M. Fox, editors. Butterworth and Co., Ltd., London. 129-155.

19. Gullo, J. J., C. Litterst, P. Maguire, B. L. Sikic, D. F. Hoth, and P. V. Woolley. 1980. Pharmacokinetics and protein binding of cis-dichlorodiammineplatinum (II) administered as a one-hour or a twentyhour infusion. Cancer Chemother. Pharmacol. 5:21-26.

20. Casper, E. S., D. P. Kelsen, N. W. Alcock, and C. W. Young. 1979. Platinum concentrations in bile and plasma following rapid and 6 hour infusions of cis-platinum. Cancer Treat. Rep. 63:2023-2025.

21. Zwelling, L. A., T. Anderson, and K. W. Kohn. 1979. DNAprotein and DNA interstrand cross-linking by cis- and trans-platinum(II)diamminedichloride in L1210 mouse leukemia cells and its relation to cytotoxicity. Cancer Res. 39:365-369.

22. Kohn, K. W., R. A. G. Ewig, L. C. Erickson, and L. A. Zwelling. 1981. In DNA Repair. E. C. Friedberg and P. C. Hanawalt, editors Marcel Dekker, Inc., New York. 379-401.

23. Roberts, J. J. 1983. In Cancer Chemotherapy. H. Pinedo and B. A. Chabner, editors. Excerpta Medica, Amsterdam. 107-119.

24. Dresch, C., Y. Najean, and J. Bauchet. 1975. Kinetic studies of ${ }^{51} \mathrm{Cr}$ and $\mathrm{DF}{ }^{32} \mathrm{P}$ labelled granulocyte. Br. J. Haematol. 29:67-81.

25. Craddock, C. G., R. L. Longmire, and R. McMillan. 1977. In Hematology. W. J. Williams, E. Bentler, A. J. Erslev, and R. W. Rundles, editors. McGraw-Hill, New York. 920-936.

26. Johnson, D. C., D. W. Leudke, R. A. Sapiente, and R. B. Naidu. 1980. Acute lymphocytic leukemia in a male with germ cell carcinoma. A case report. Med. Pediatr. Oncol. 8:361-365.

27. Mead, G. M., J. A. Green, F. R. Macbeth, C. J. Williams, and J. A. M. Whitehouse. 1983. Second malignancy after cisplatin, vinblastine, and bleomycin (PVB) chemotherapy: a case report. Cancer Treat. Rep. $67: 410$.

28. Rajewsky, M. F., L. H. Augenlich, H. Biessman, R. Goth, D. F. Hulser, O. D. Laerum, and L. Ya Lomakina. 1977. Nervous systemspecific carcinogenesis by ethylnitrosourea in the rat: molecular and cellular mechanisms. Cold Spring Harbor Conf. Cell Proliferation. 2:709726.

29. Bradley, M. O., S. Patterson, and L. A. Zwelling. 1982. Thiourea prevents cytotoxicity and mutagenicity but not sister-chromatid exchanges in V79 cells treated with cis-diamminedichloroplatinum (II). Mutat. Res. 96:67-74.

30. Ehrlich, C. E., L. Einhorn, S. D. Williams, and J. Morgan. 1979. Chemotherapy for stage III-IV epithelial ovarian cancer with cis-dichloroplatinum (II), adriamycin, and cyclophosphamide: a preliminary report. Cancer Treat. Rep. 63:281-288.

31. Armitage, P. 1971. Statistical Methods in Medical Research. Blackwell Scientific Publications, Oxford. 504 pp.

32. Wintrobe, M. M., G. R. Lee, D. R. Boggs, T. C. Bithell, J. Foerster, J. W. Athens, and J. N. Lukens. 1981. The lymphatic system. In Clinical Hematology. M. M. Wintrobe, editor. Lea and Febiger, Philadelphia. 271-293. 